Article

\title{
From Food Waste to Donations: The Case of Marketplaces in Northern Spain
}

\author{
Pilar L. González-Torre * and Jorge Coque
}

Department of Business Administration. University of Oviedo, Viesques Campus. Wifredo Ricart s/n. 33204

Gijón (Asturias), Spain; coque@uniovi.es

* Correspondence: pilargt@uniovi.es; Tel.: +34-985-18-1995

Academic Editor: Giuseppe Ioppolo

Received: 17 March 2016; Accepted: 14 June 2016; Published: 18 June 2016

\begin{abstract}
There is a growing increase in the number of disadvantaged people whose basic needs, such as food, should be covered. In crisis periods, food banks and other entities have a special role to play in that social function. This research focuses on the marketplaces that are great generators of organic food waste due to the fact that almost all of their stalls are dedicated to the sales of fresh food. The work combines both qualitative (interviews with the person responsible for most of the marketplaces in a northern Spain region and with two health inspectors, as well as a participatory workshop with different stakeholders related to food recovery: a regional waste management company, a food bank and several beneficiary entities) and quantitative techniques (a massive survey of the market stalls where the interviews were previously conducted). The results allow us to estimate the volume of organic waste generated by these marketplaces and to propose guidelines that would facilitate a better management of the food surpluses with potential for use, in the first place, as donations to food banks and, secondly, as recoverable bio-waste.
\end{abstract}

Keywords: marketplaces; food banks; bio-waste; donations; northern Spain

\section{Introduction}

Millions of people around the world live below the poverty line. In developing countries, in $2010,21 \%$ of people were living on $\$ 1.25$ a day or less [1]. In the period of 2011-2013, 842 million people (one-eighth of the world's population) suffered chronic hunger. Due to the latest economic crisis, the advances seem to have slowed down, but the geographical differences have increased, even affecting industrialized countries, such as Spain [2].

In contrast to this situation of unsatisfied basic needs, the phenomena of food losses and waste are observed. On the one hand, food losses are defined as the decrease in the mass of edible products by humans in the stages of production, post-harvest and processing into the supply chain; on the other hand, food waste occurs at the end of the supply chain and is related to the inappropriate behavior of retailers and consumers [3]. About one-third of food produced for human consumption is lost or wasted; this figure represents about 1300 million tons per year [4]. In most high-income countries, the food is mainly wasted; this means that food is thrown away while still in a suitable condition for human consumption (for example, in the USA, $40 \%$ of food goes uneaten daily [5]); in low-income countries, food losses exceed the amount of food waste, which clearly denotes technological shortcomings. Therefore, an American consumer wastes 10-times as much food as a Southeast Asian [6].

More than 100 million tons of food were wasted in Europe in 2014 [7]. Spain is the sixth European country with the most wasted food (about eight million tons) after Germany, Holland, France, Poland and Italy [8]. The main cause of this waste is the leftovers produced during meals at the consumption stage $(86.4 \%)$ [9], while in the distribution system, the main reasons are non-perishable mislabeled 
items, canceled orders, line endings, completed promotions, damaged units, but still suitable for consumption, or incorrect packaging [10].

In addition to this social problem, especially in developed societies, the role played by food banks is crucial. A food bank can be defined as a non-profit organization based on voluntary activity whose aim is to recover food surpluses from society and redistribute them to those in need, avoiding any waste or misuse [11,12]. In addition to this definition, within the literature review, there are many other authors who have tried to define the concept. For Cotugna et al. [13], food banks are stores for collecting donations of food surpluses and distributing them to other non-profit organizations. This last idea related to distribution is the focus of the definition in other research, e.g., Martins et al. [14]. Handforth et al. [15] state that food collected and distributed by such entities is usually packaged, fresh or frozen, and beverages. In this context, food banks play the role of the "good Samaritan"; although not applicable universally, in the USA and Canada, the saying is widely used to protect someone who tries to serve or help with respect to needs and well-being.

From the previous definitions, we can deduce that food banks maintain a bridge between the food surpluses in producing industries and the rest of society, on the one hand, and the most immediate and basic human needs, i.e., transforming food into solidarity/caring resources, on the other. Each food bank depends on what their "providers" (donor companies and others) bring or contribute, and thus, part of their clients' demand (beneficiary organizations) can be satisfied (Figure 1). Being run by its offering, and not by its demand, represents the opposite logic to that of every commercially-conventional supply chain and brings serious management problems.

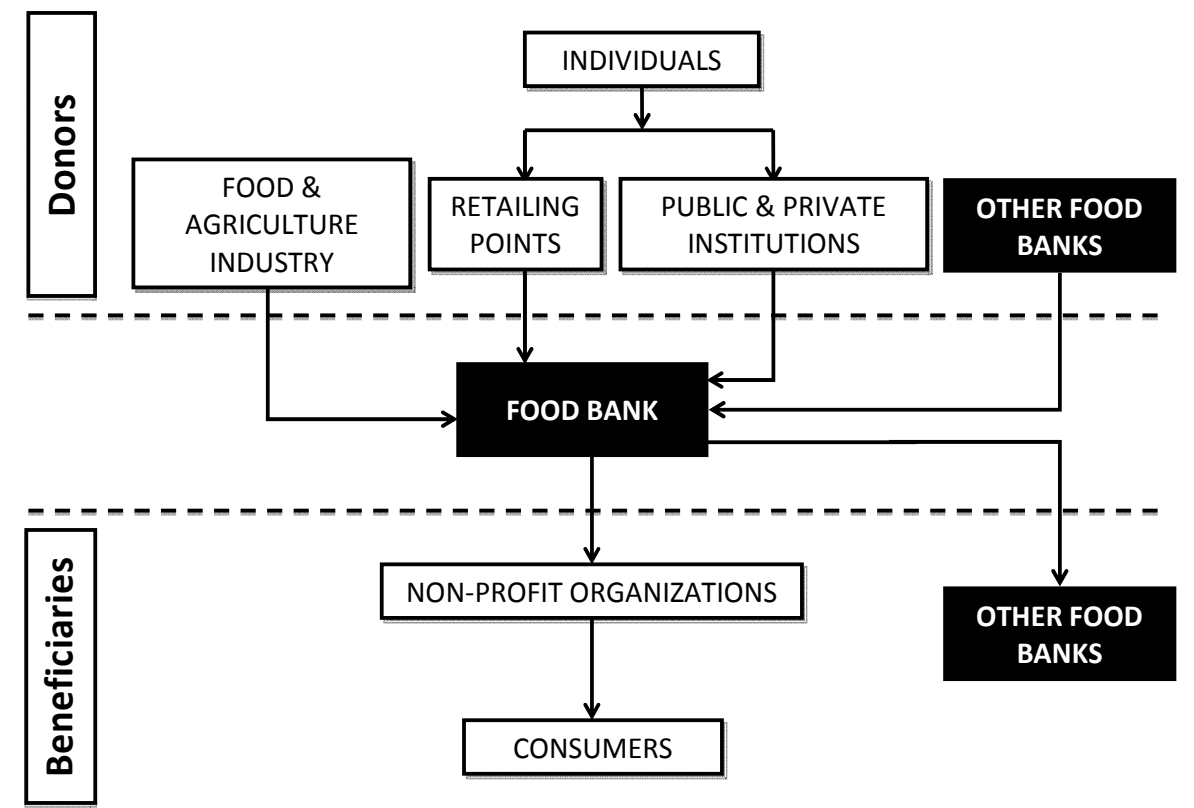

Figure 1. Position of food banks in the logistics chain [16].

In Spain, there is around one food bank per province, making a total of 55 entities nationwide [17]. The Food Bank of Asturias, created in 1997, currently covers the needs of 27,000 people through nearly 200 social non-profit entities [18]. Asturias is a northern autonomous one-province community with a little over 10,000 square kilometers and 1,000,000 inhabitants.

This research focuses on the marketplaces of Asturias as large producers of food waste from fresh items and therefore as potential donors of food to collection centers in need through the food bank in the region.

On the one hand, marketplaces belong to the processing and packaging step in the food supply chain, where food recovery or redistribution is really relevant. Food recovery is the collection of 
wholesome food for distribution to the poor and hungry. On the other hand, food banks are the recovery organizations responsible for collecting and transporting food donations, although food ready for donation does not always match the needs of food recovery organizations [5] (p. 14).

Another challenge is the reduction of bio-waste quantities going into landfill; or the reduction of the great amounts of natural resources associated with discarded food [19]. Bio-wastes are defined as biodegradable garden and park waste, food and kitchen waste from households, restaurants, caterers and local retailers and similar residues from food-processing plants [20].

A marketplace is a set of retail shops, usually selling food, normally grouped within a building of great historical and artistic interest [21]. A solution for managing the remains of food sold in these shops would be the separation of the surplus into two parts: firstly, the usable products would be sent to social entities coordinated by a food bank; and what cannot be reused must be placed in specific bio-waste containers.

There are a few relevant experiences regarding perishable food recovery in marketplaces in Spain. One is the case of the local marketplaces of Cornella de Llobregat (Barcelona) and Torredembarra (Tarragona), whose councils coordinate all of the necessary steps for food recovery implementation. In the first case, the transport of food is carried out by Red Cross volunteers, and the final recipient is the Botiga Solidaria, which helps more than 600 families [22]. Regarding Torredembarra, this is a weekly marketplace of fruit and vegetables whose surpluses are sent to Rebost dels Aliments Torredembarra, an entity belonging to Caritas, which serves about 200 families [22]. During 2013, 2571 $\mathrm{kg}$ of food were collected in Cornella and 5103 in Torredembarra, representing economically $€ 8237$ in the first case and $€ 10,425$ in the second [22].

Within the wider research on the situation, the management and the potential of Spanish food banks' framework, this paper focuses on the first link in the supply chain (Figure 1), paying particular attention to one of the major producers of food and agricultural waste, specifically the marketplaces in Asturias, as a source of food for needy groups.

In other words, it seeks to address the following research question: do marketplaces in Asturias encompass an interesting potential to recover organic waste, either as consumable food or recoverable bio-waste? In the case of an affirmative answer, other issues will be considered, such as the amount of food that can be recovered or if/how these figures could be improved.

The specific objectives to respond to these research questions are established as follows:

- Conduct a study of marketplaces in Asturias, focusing on facilitating the separation of food as donations to organizations, such as the Food Bank of Asturias, or as recoverable bio-waste.

- Develop guidelines to better manage food surpluses, as well as waste and, in particular, bio-waste, in this kind of commercial area.

The generalizable goal of the research is then proposing ways to advance on the challenge of transforming food waste into food donation. The paper focuses on food waste management in the retail trade in order to improve the supply of food redistribution. As this is a topic only lightly treated in the current literature, the present work offers a multi-case study that could (and should) be replicated and adapted to other contexts, building gradually useful knowledge for social purposes.

In the next section, the methods used in this research are briefly explained. The main results (of the qualitative analysis, firstly, and of the quantitative study, secondly) are presented in Section 3. Finally, a discussion and relevant conclusions are included in Section 4.

\section{Methods}

After an in-depth literature review, consisting of the compilation of previous studies on the central themes of the project (data on poverty and hunger; losses and food waste; food banks and food recovery; marketplaces), to achieve the objectives of this research, a combination of different methodological tools has been applied: 
- Expert opinion: meetings with people from different entities (waste manager, food bank responsible, some of the beneficiary entities of the food bank and a representative of the food retail sector).

- Qualitative study by means of interviews with the representatives of most marketplaces in Asturias and two health inspectors, as well as a participatory workshop. This step of the research allows having a complete overview of the marketplaces studied.

- Quantitative study by surveying shops in marketplaces in which interviews were conducted previously during the qualitative study. In this last step, more details are obtained about the analysis unit.

\section{Results and Discussion}

\subsection{Qualitative Analysis}

Initially, we wanted to obtain an overview of the current situation of Asturian marketplaces, emphasizing their waste management, especially the organic part; therefore, we chose a qualitative exploratory analysis.

Indeed, qualitative research methods contribute to the understanding of organizational or social systems, taking into account contexts and diffuse phenomena, proposing appropriate solutions for particular situations and offering descriptions to substantiate subsequent generalizations [23,24].

This does not detract from the rigor of the work processes. In this case, the data collected (interviewees' opinions and documentation provided by them) were compared using various instruments applied sequentially to ensure external validity, internal validity and reliability of the research [25]:

- Saturation of information, through eight in-depth interviews with informants related to marketplaces that were different from each other, but complementary: managers, administrators or others (in cases where no one was exclusively in charge of the marketplace management), as well as two health inspectors. The interviews were conducted face to face and followed a semi-structured questionnaire, elaborated for the research team of the University of Oviedo, the waste manager entity in the region studied and the Food Bank of Asturias. The interviews took place between October 2014 and April 2015, the length of each one being between 15 and $30 \mathrm{~min}$.

- Coding: The two ways of coding of Strauss and Corbin [26] were used. Firstly, open codes, i.e., after a first reading of the interviews, words or pieces of text that called for attention were highlighted. Secondly, we proceeded to perform an axial coding; this means that second categories and subcategories were generated, and then, the relationships among them were established.

- Discussion within the research team: Each member made their own map of categories based on the transcript of the interviews, which were subsequently verified and discussed with the rest of the team to reach consensus.

- Contrast and complementarity of interviews with documentary sources: plans, lists of jobs and activities and memories with an overview of the marketplaces.

- Additional contrast by having a workshop (that took place on 2 December 2014) to return to and deepen the provisional results of the qualitative study. This workshop was moderated by the research team at the University of Oviedo and conceived of from a perspective of participatory action research. Such a methodological approach begins with direct social academic commitment, calling into question who is the researcher and who the researched, whose respective traditional roles of subject and object in the study fade and exchange to build the truth together [27]. Researchers provide support to the community (in this particular case, the Food Bank of Asturias and its beneficiary entities and other actors situated "upstream" in the supply chain) to analyze their problems throughout mutual training processes. 
- In particular, reliability was ensured by the prior literature review, which provided the content and structure of the script for interviews, the recording and transcription of these and, in general, by the systematization of all information collected and the monitoring of a rigorous protocol for the entire process.

\subsubsection{Interviews with the Managers of Marketplaces}

The population, taken from a total of 14 marketplaces in the Asturian region, was established from a public directory [28]. This population was verified and supplemented via the Internet and by phone calls. In the study, the unit of analysis is the unit of management of the marketplace in each council. Those belonging to the 12 councils involved were contacted by telephone. Finally, we were able to interview eight managers with respect to nine marketplaces located in seven different councils (first column of Table 1). The second column of Table 1 includes the number of the respective available shops, which is important given the relationship between the total food surpluses and the marketplace occupation grade. The third column shows the number of open operating shops, which is used to estimate the actual food surpluses produced.

Table 1. Information about each marketplace shop (based on the interviews, the documentation provided by each marketplace and direct observation).

\begin{tabular}{ccccc}
\hline Marketplace & $\begin{array}{c}\text { Number of } \\
\text { Available Shops }\end{array}$ & $\begin{array}{c}\text { Number of Open } \\
\text { Operating Shops }\end{array}$ & Total Surface $\left.\mathbf{( m}^{\mathbf{2}}\right)$ & $\begin{array}{c}\text { Shops' } \\
\text { Surface } \mathbf{( m}^{\mathbf{2}} \mathbf{)}\end{array}$ \\
\hline 1 & 21 & 18 & 1000 & 540.00 \\
2 & 42 & 38 & 2000 & 920.04 \\
3 & 42 & 34 & 1630 & 710.00 \\
4.1 & 32 & 5 & - & 730.36 \\
4.2 & 14 & 4 & - & 750.23 \\
5 & 16 & 9 & 519 & 151.22 \\
6.1 & 16 & 3 & 247 & 237.00 \\
6.2 & 3 & 36 & 6000 & 78.00 \\
7 & 58 & & & 954.00 \\
\hline
\end{tabular}

It is important to point out that the study included municipal marketplaces and commercial shops similar to them, but that were under private property (both share the characteristics of permanently-covered marketplaces, and both are mainly devoted to selling fresh or perishable food, where the customer is the final consumer). Table 2 outlines the basic conceptual blocks of the script used in the interviews.

Table 2. Script of interviews with marketplaces' managers.

\begin{tabular}{llc}
\hline \multicolumn{1}{c}{ Blocks } & \multicolumn{1}{c}{ Contents } & \multicolumn{1}{c}{ Sources } \\
\hline $\begin{array}{l}\text { A. Information about } \\
\text { the marketplace }\end{array}$ & $\begin{array}{l}\text { General (property, number of shops, available surface) } \\
\text { Situation (types of purchase) }\end{array}$ & {$[21,29-33]$} \\
\hline \multirow{2}{*}{ B. Waste management } & Practices (who is responsible for waste management) & {$[21]$} \\
& Containers (types of them) & {$[21,32]$} \\
\hline \multirow{2}{*}{ C. Wastes generated } & Features (types of them) & {$[21]$} \\
& Donations (potential of food surplus) & {$[22]$} \\
\hline
\end{tabular}

Food markets are a traditional commercial form [29]. There are diverse cases of marketplaces in terms of the characteristics of each one in relation to its size and capacity, age and style, number of floors, state of the facilities and style of management [30]. Thus, some of them are located in ancient/historic buildings [31] and others in more recently-built areas; sometimes marketplaces have been remodeled to adapt old facilities to current needs. Furthermore, many marketplaces have disappeared or require a 
physical, functional and operational modernization, while others can compete successfully nowadays with other retail formats [32]. Marketplaces have certain strengths that should be properly exploited to remain in the current scenario, such as the quality and variety of supply, the proximity to demand, the personalized service and the concentration of supply that avoids the need for lengthy shopping [33].

Usually, marketplaces are local utilities owned by the town hall. They can be managed directly by the local government or by third parties [31]. This trend is illustrated in the Asturian case where all of the marketplaces studied are local authority property, except for Market 7, which is privately owned. In the indirect management, only the concession model is observed in the cases studied. Markets 1 and 2 are handled through administrative concessions. Other marketplaces within municipal property are managed directly by the respective town halls.

In the local marketplaces, more than $80 \%$ of outlets are food [21]. During daily activity, the distributions of perishable or fresh, fruit, vegetables, fish and meat have become essential products. Table 1 summarizes the information about the shops in each marketplace studied. An available space is the surface on which a commercial shop is located. One shop may have several spaces. An open operating shop is one that is open to the public. The total area is the surface occupied by the whole marketplace, including the shop's spaces, public access and ancillary facilities.

In recent decades, trade in general and local marketplaces in particular have suffered important changes resulting mainly from changes in consumer habits. That means that the commercial supply of shopping centers must offer different alternatives that combine shopping and leisure facilities [34]. Over several decades, local marketplaces were an effective way to ensure retailing offering daily purchases, especially food, in times of high demand growth and with high quality standards. Currently, there are local marketplaces having difficulties to the point that in some Asturian places, their survival is in danger [35]. Some marketplaces have adopted new business strategies to recover part of their past success. In other locations, the custom of buying in local marketplaces rather than supermarkets is prevailing, especially for buying certain fresh products due to the capability of marketplaces to offer several advantages: specialization, product quality, personalized services, etc. Regarding the decline in the number of shops and sales, the answers are different, although the acceptance of that fact seems clear. Several marketplaces have changed their location because they were located in large buildings whose space was not all being used because they had begun to need smaller areas.

Local marketplaces have traditionally been regarded as local large waste generators, because they are collective enclosures for public attendance and daily activity. In each marketplace, a person must be responsible for waste management, although the manager in charge of the collection service in the marketplace may be different from the company that has been contracted for the collection of waste generated in the rest of the city/town. In addition, the concierge, although not common in all marketplaces, could have the internal waste collection among his/her tasks [21].

Some marketplaces have an internal warehouse in which to locate the containers, but have only one type of container (dark green for the remaining waste); however, others use public containers that are also used by all citizens. Most marketplaces throw their waste out in bags, although some throw it out without bags. For this latter behavior, containers must be cleaned daily; the use of bags, especially for organic waste, such as meat and fish, is important [21].

For a typical Spanish marketplace, the average composition of waste generated is dominated by organic material (76\% in total), because, as already mentioned, the vast majority of shops sell food [21].

Preventing food waste is one of the main ways to reduce organic waste. Voluntary agreements with social organizations for the use of surplus food fit perfectly into the current socioeconomic period [22]. Given their major activity, local marketplaces have large volumes of food surpluses that could be transformed into donations for needy people. This practice remains vague in the cases studied, except in one marketplace, where more or less systematic donations are made. 


\subsubsection{Participatory Workshop}

The most important conclusion of the workshop, held in December 2014 with the participation of representatives of the main stakeholders of the research, is the fact that the beneficiary organizations of the Food Bank of Asturias are demanding greater quantities of fresh food. A part of this need could be met through food surplus from marketplaces.

Members of the Food Bank of Asturias showed an interest in the "upstream" research of potential suppliers' entities, but expressed doubts as to whether "all foods can be donated". These doubts were shared by other attendees.

The waste management company in Asturias (only a mixed capital, public and private-firm for all of the region) receives large amounts of food surplus from the marketplaces, which end up in the anaerobic digestion plant. Exploiting them in previous phases should be tried because in most cases, these food surpluses are fit for human consumption. In addition, the waste management company representative raised the possibility of generalizing the experience of donations previously observed in some other marketplaces.

To end the discussion, several participants explained that technological processes should be applied both to ensure legal compliance and to stop food deterioration. For example, products such as tomatoes could be transformed into bottled sauce to lengthen their shelf life. Food should be prepared, canned, vacuum packaged, etc., which would be donated instead of fresh food.

In sum, the workshop supported the interest of continuing research and suggested interviewing health inspectors to clarify some controversial issues concerning the food security of potential donations.

\subsubsection{Interviews with Health Inspectors}

To use food waste for human consumption, it must be safely handled, and all means to reduce the risk of poisoning must be also used [36]. In order to clarify this aspect, which generated an unresolved debate in the workshop, two health inspectors were interviewed, following a script previously agreed upon with experts of waste management and the Food Bank of Asturias (Table 3).

Table 3. Script for interviews to health inspectors.

\begin{tabular}{clc}
\hline Blocks & \multicolumn{1}{c}{ Contents } & Sources \\
\hline \multirow{2}{*}{ A. Food } & $\begin{array}{l}\text { Type of food to donate } \\
\text { State of food that can be donated (risk of poisoning) }\end{array}$ & {$[37]$} \\
& Staff (number and training for food handling) & {$[36,38]$} \\
\hline \multirow{2}{*}{ B. Collection } & $\begin{array}{l}\text { Hygiene measures (temperature-cold chain) } \\
\text { Pickup time }\end{array}$ & {$[36,39]$} \\
& Periodicity (number of times that the surplus is collected) & {$[22,38]$} \\
\hline \multirow{2}{*}{ C. Delivery } & $\begin{array}{l}\text { Delivery methods } \\
\text { Means of transport (guarantee of temperature maintenance) }\end{array}$ & {$[36,37,40]$} \\
& $\begin{array}{l}\text { Rules for transport (legislation) } \\
\text { D. Other factors }\end{array}$ & Critical points (security standards, recipient entities) \\
\hline
\end{tabular}

The interviews began by asking about food that can be donated from marketplaces. Regulation (EC) No. 178/2002 of the European Parliament and of the Council of 28 January 2002 states that unsafe food cannot be marketed [37]. Therefore, only food "suitable for consumption" could be donated. Regarding the state of food that can be donated, one of the inspectors indicated that food must be donated within the dates of consumption and with packaging integrity, as well as without any signs of deterioration or putrefaction.

The second set of questions dealt with the issue of collection. The food that is donated must be stored at the required temperature for proper storage in a separate place from other food and correctly identified [36]; packaged food usually indicates that temperature on its label. In the marketplace 
itself, the requirements for donations start with proper storage, guaranteeing the cold chain, stowage and transport as indicated by the manufacturer (if the items of donated food are packaged products). Before accepting the donation, it is necessary to check that the shop donor has good facilities and hygienic conditions [36]. Then, staff training in food hygiene is recognized as one of the basic pillars to ensure proper implementation of the requirements at each stage in order to achieve safe food. In addition, volunteers who distribute food must have the necessary training to ensure hygienic handling [36]. Regarding hygiene measures, there is nothing mandatory, but of particular interest are staff clothing, the application of clean utensils that are in good condition, gloves for a single use and personal hygiene.

Another key factor is the pickup time, ensuring that it does not interfere with the normal activity of the shop, i.e., recommended to be in the final hours of the day. In the experience of surplus channeling in the marketplace of a Catalonian town, the collection and subsequent storage in the cold storage area of the marketplace took place in the late morning, prior to closing [22]. However, in the experience of another Catalonian town, fresh food was collected in the morning, and by the afternoon, it was already in the hands of the beneficiary groups [38].

It must also be checked that the collected food is fit for human consumption. In Reus, the distribution chains and the marketplace participants for donations were responsible for collecting and selecting food, and then a special working center with people with intellectual disabilities performed a second screen following the instructions of the Agency of Public Health [38]. In Asturias, social entities distributing "downstream" of the food bank area should ensure that each product has been properly kept at the temperature that the package label indicates or at the regulated temperature if the product is unpackaged.

Delivery is the third point addressed in the interviews, where the role of temperature is clear as a factor to consider in conservation, even during transportation; if a refrigerated vehicle is not available, it is appropriate to use containers or an isothermal sheath with a cold source, and the transport time must be limited to one and a half hours to keep products at the right temperature [36]. Concerning the frequency, the number of times that the surplus is collected is relevant, because most of the food is highly perishable, i.e., fresh items, and also logistics costs have to be taken into account. Delivery should also take care of the delivery method: non-reusable materials and suitable for contact with food in the case of unpackaged food. Legislation insists on the need to maintain the cold chain for products that need it and to have clean vehicles whenever a transportation takes place.

Other factors to consider are security standards/rules for transport (agreement on international transport of perishable goods and special vehicles, which establishes the obligation to have refrigerated vehicles or isotherms for a set of products and to respect certain temperatures) and the people responsible for this task (with emphasis on hygiene and training in food handling). On the one hand, the legal requirements for transporting and storing food do not discriminate among food destinations, being indifferent to having an altruistic or commercial purpose. This is not true in all countries; in the United States and Italy, for example, requirements vary according to the social objectives and the type of agreement between the donor and the recipient [40]. On the other hand, the recipient institutions must ensure receiving a delivery order by the donor for traceability control [36]. Traceability allows investigation into whether food is considered compliant or not, locating it along the distribution chain and removing it if necessary.

Finally, another important aspect is that once food is accepted by the beneficiary entities, it is necessary to ensure that its temperature does not exceed what has been established for proper conservation and that cooled and frozen products are quickly saved [36].

The two health inspectors interviewed made it clear that food from marketplaces can be donated, relying on EC Regulation 178/2002 [37]. Then, safe food, i.e., food "fit for consumption", could be donated by the shops of these marketplaces to organizations such as food banks or soup kitchens. To avoid problems, it is desirable that agreements between food business donors and recipient organizations are reflected in writing, clearly stating that it is edible food for human consumption 
and complies with all national and community guarantees for commercialization. Additionally, the organizations must assume the commitment to transport and store the food under proper conditions until consumption.

\subsection{Quantitative Analysis}

The qualitative methodology applied previously allowed the exploration of an initially unknown reality, but showed a lack of the generalization of the data collected, and these were too aggregated (they had been obtained marketplace to marketplace). For this reason, a quantitative transversal research was undertaken on the set of Asturian marketplaces studied and focused on the traders of the different food shops located in those marketplaces. The manager of each marketplace is generally responsible for making available the resources and public administration, usually local, for planning the management needs and for waste control and management [34]. However, traders, as the main generators of waste, should be aware of their important role in the adoption of measures to help improve waste management without losing the quality service they provide [21]. They have the current problems of the massive increase in food waste, so the role of marketplaces in the appropriated channeling of these surpluses must be analyzed in detail.

Then, the next step of the research was justified by the deepening of the topics covered in the qualitative analysis, extending the approach to hybrid logic, i.e., qualitative-quantitative [41].

In this second step, we extended the research to the food sale shops in each marketplace to obtain information from the point of view of traders on infrastructure, services and management, their current status and operation, also describing their overview with a focus on daily logistics management of waste and investigating aspects that had remained unclear in the qualitative analysis, such as food donations.

Surveys were conducted in nine of the 14 Asturian marketplaces (Table 4) belonging to seven different councils. The confidence level refers to the percentage of all possible samples that can be expected to include the true population parameter [42]. In our sampling, the confidence level is $95 \%$, which implies that the $95 \%$ of the confidence intervals would include the true population parameters. The sample error refers to the precision of the statistical estimate [43].

Table 4. Survey sheet.

\begin{tabular}{cc}
\hline Target Population & Asturian Marketplaces \\
\hline Analysis Unit & Food shop \\
Sample Size & 150 food shops \\
Response Rate & $73.33 \%$ (110 food shops) \\
Confidence Level & $95 \%$ \\
Sample Error & $4.84 \%$ \\
Method & Survey face to face \\
Period & 14 November 2014-21 April 2015 \\
\hline
\end{tabular}

The sample is considered representative because, as shown in Table 5, the five marketplaces not studied (i.e., those whose managers had not been able to be interviewed in the qualitative study) have a relatively low number of food shops (only $14.30 \%$ ). The survey is also the most appropriate research methodology because the target population is relatively large (Table 5). Therefore, we pursue now in detail and in depth the information that confirms the need for a quantitative technique [44].

The research team at the University of Oviedo designed the questionnaire after meeting with experts where a brainstorming session was undertaken based on information and considerations obtained in the literature review and the previous qualitative study. A subsequent pre-test was conducted in two food marketplaces belonging to the same council. This pre-test suggested some additional amendments to the draft. The final survey is divided into the blocks shown in Table 6. 
Table 5. Shops in Asturian marketplaces.

\begin{tabular}{|c|c|c|c|c|}
\hline Marketplace & & $\begin{array}{l}\text { Number of } \\
\text { Open Shops }\end{array}$ & $\begin{array}{l}\text { Number of } \\
\text { Food Shops }\end{array}$ & $\begin{array}{c}\text { Number of } \\
\text { Surveyed Shops }\end{array}$ \\
\hline \multirow{10}{*}{ Marketplaces studied } & 1 & 18 & 16 & 13 \\
\hline & 2 & 38 & 35 & 31 \\
\hline & 3 & 34 & 27 & 17 \\
\hline & 4.1 & 25 & 24 & 17 \\
\hline & 4.2 & 5 & 5 & 4 \\
\hline & 5 & 4 & 3 & 2 \\
\hline & 6.1 & 9 & 9 & 5 \\
\hline & 6.2 & 3 & 3 & 1 \\
\hline & 7 & 36 & 28 & 20 \\
\hline & Subtotal & 172 & 150 & 110 \\
\hline \multirow{7}{*}{ Marketplaces not studied } & 8 & 8 & 7 & - \\
\hline & 9 & 9 & 7 & - \\
\hline & 10 & 4 & 2 & - \\
\hline & 11 & 7 & 5 & - \\
\hline & 12 & 6 & 4 & - \\
\hline & Subtotal & 34 & 25 & - \\
\hline & Total & 206 & 175 & 110 \\
\hline
\end{tabular}

Table 6. Outline of the survey of shops in marketplaces.

\begin{tabular}{clc}
\hline Blocks & \multicolumn{1}{c}{ Contents } & Sources \\
\hline & Activity (what is sold) & {$[30,34]$} \\
Information about the shops & Surface & {$[32]$} \\
& Availability of cold facilities & {$[33,36]$} \\
& Timetable for public attendance & {$[30]$} \\
\hline Clients & Daily quantity & {$[33,34]$} \\
\hline \multirow{2}{*}{ Waste generated } & Types (paper and cardboard, organic fraction, glass, etc.) & {$[21]$} \\
& Reasons (why is waste generated) & {$[36]$} \\
\hline \multirow{2}{*}{ Waste management } & Separation (possible or not) & {$[21,29]$} \\
& Methods of waste management & {$[32]$} \\
& Surpluses (types and quantities) & {$[8,22]$} \\
& Donations (types and quantities) & \\
& Begin to donate (asking about possibilities) & {$[22]$} \\
\hline
\end{tabular}

The first block refers to general data about every stall. An important fact in this section is the activity of the marketplaces, traditionally engaged in selling fresh products with extra quality [34]. For this reason, marketplaces occupy a strong position in the distribution of fruit, vegetables, fish, meat and charcuterie [30].

With respect to the surface area of each shop, many marketplaces require a minimum for this figure. In the case of fresh food stalls, the optimal dimensions can be set between 15 and 20 square meters of retail space, depending on the size and type of marketplace where they are located [32].

To achieve successful results in this research and due to the fact that the marketplaces develop a commercialization of perishable goods [33], the availability of cold systems to preserve the products is relevant information to obtain. As they are proposed to be fresh food donations, we must ensure that they have been properly preserved at the required temperature by maintaining the cold chain [36].

Nowadays, it is necessary to introduce certain changes to the marketplaces to compete with more modern commercial formulae. One of these changes is a broader timetable adapted to the new needs of customers [30]. 
The second block in Table 6 is relatively short and focuses on the kinds of customers that attend this type of point of sale (individuals, restaurants or others), because they will affect sales and billing. The most common commercial business is to attend to the final consumer [34]. Generally, housewives are the biggest group of shoppers in municipal marketplaces (52\%), followed by employed $(27 \%)$ and retired people $(16 \%)$, unemployed people $(4 \%)$ and students $(1 \%)$, being the smallest group of buyers in the marketplaces [33].

The third section deals with questions related to waste generated. The aim is to know in detail the type of waste from each type of stall in the marketplace and the reasons for it. As already discussed in the previous qualitative analysis (see Section 3.1), in a marketplace, the greatest amount of waste is composed of the organic waste, followed by cardboard [21].

Surpluses are generated, and food is thrown away. In order to reduce waste at its source, it is important to know the reasons why food is thrown away in marketplaces: defects in packaging, poor appearance of the item, expiry date or overproduction [36].

The fourth and last block of questions deals with waste management. Marketplaces are one of the main purchase channels for fresh items, and traders who develop their activity in them have to take the necessary measures to improve the quality of their services and simultaneously to protect the environment [29]. Recently, domestic waste has increased significantly in cities, becoming a concern for society. Therefore, affordable and simple solutions based on habit changes and infrastructure collection and treatment must be considered [21]. Then, each trader's decision to carry out proper waste separation is really crucial.

A study undertaken in 2007 on the improvement of marketplaces' management [32] shows that information and education campaigns aimed at traders and market managers were very efficient. Therefore, it is necessary to know if these types of campaigns have been conducted in the marketplaces studied.

Butchers and fishmongers in marketplaces must manage their waste through companies that transform it into other usable products, which will be an indicator of the degree of commitment to waste management in each marketplace. In these stalls, it is also important to throw away organic waste into the container (the right way is in bags), because they can stain the container and produce bad odors. A clean look of all spaces commonly used in the marketplace is an essential factor to make the action of buying a pleasant one [32].

Surplus food channeling is an opportunity for waste prevention with a strong social impact that has an increasing implantation [22]. Then, creating pathways for the use of food surplus that cannot be offered for sale due to different reasons could be the right way to solve this social problem [8]. One of these pathways could be food banks. Apart from the environmental and economic benefits (due to the reduced requirements of collection and treatment), this performance incorporates social added value. The issue of donations was not entirely clear in the qualitative analysis, so it will be analyzed in depth by means of the quantitative study. The collection of surplus from different stalls and their subsequent storage in the refrigerator may be the best way to keep food in good condition [22] to achieve such social goals.

Face to face surveys were carried out in all of the marketplaces studied before. From the 172 shops that are presently open in these 10 marketplaces, only 150 are food sellers.

Surveys took place from 14 November 2014-21 April 2015. At the end of the interviews with the managers of marketplaces, the need for surveying to fulfill the research was considered and explained. Therefore, in most cases, the interviewed managers were the link to contacting people in charge of each shop.

Once the fieldwork was finished, a database with all of the collected information was prepared for the subsequent analysis of the data (see Sections 3.2.1-3.2.3). 


\subsubsection{Descriptive Analysis of Data Collected in Food Shops}

The shops dedicated to meat selling represent $30.8 \%$ of total shops in Asturian marketplaces, fish $17.4 \%$, fruit and vegetables $14.5 \%$ and cooked meats $11.6 \% ; 7.6 \%$ are bakeries; $4.7 \%$ other food shops; and $0.6 \%$ are frozen foods. Regarding the surface area of each facility, the average is $18.82 \mathrm{~m}^{2}$. The shops are open an average of $45 \mathrm{~h}$ per week, serving the public about seven hours a day, and $94 \%$ of shops have cold storage facilities to preserve products.

An average of 74 customers come to each facility per day, although the data vary widely (the maximum is 500 customers a day).

Eighty one percent of shops generate paper and cardboard waste, and $78 \%$ is the organic fraction (meat or fish is $60 \%$, fruit and vegetables 18\%). The percentage of organic waste does not reach $100 \%$ because some shops, such as delicatessens, bakeries or others, say they do not generate this type of waste, or they do so in insignificant amounts, or surpluses are collected by the supplier.

The daily amounts of waste that are generated at each shop allow us to estimate the distribution in weight by each kind of waste (see Table 7), which is directly related to the activity. On the one hand, the line "average" refers to the average value obtained with the sample data; on the other hand, the sum of the same data is represented in the line named "total". Meat and fish waste are the most abundant, as almost two-thirds of surveyed shops (65\%) were butchers, delicatessens or fishmongers.

Table 7. Data on daily waste.

\begin{tabular}{cccccccc}
\hline & Meat and Fish & Fruit and Vegetables & Paper & Plastic & Glass & Wood & Others \\
\hline Average (kg/day) & 15.25 & 6.42 & 2.64 & 1.03 & 0.44 & 4.64 & 1.09 \\
Total (kg/day) & 1006.7 & 128.36 & 235.21 & 60.8 & 2.64 & 64.98 & 13.06 \\
$\%$ & $66.59 \%$ & $8.49 \%$ & $15.56 \%$ & $4.02 \%$ & $0.17 \%$ & $4.30 \%$ & $0.86 \%$ \\
\hline
\end{tabular}

Tables 8 and 9 show the total generation of daily waste for different types of shop, allowing the identification of waste generated by activity and the activities that generate the most waste. Fishmongers are the highest $(45.68 \%$ total waste), followed by butchers $(28.26 \%)$ and greengrocers $(19.00 \%)$.

Table 8. Distribution of the total waste generation by type of shop (a).

\begin{tabular}{ccccccc}
\hline & $\begin{array}{c}\text { Butchers } \\
\text { (kg/day) }\end{array}$ & $\mathbf{\%}$ & $\begin{array}{c}\text { Delicatessen } \\
\mathbf{( k g / d a y )}\end{array}$ & $\mathbf{\%}$ & $\begin{array}{c}\text { Fishmongers } \\
\text { (kg/day) }\end{array}$ & $\mathbf{\%}$ \\
\hline Meat or fish & 346.48 & 82.77 & 15.1 & 25.14 & 614.21 & 90.77 \\
Fruit and vegetables & 0 & 0.00 & 0 & 0.00 & 0 & 0.00 \\
Paper and cardboard & 48.96 & 11.70 & 33.06 & 55.04 & 44.47 & 6.57 \\
Plastic & 22.98 & 5.49 & 8.25 & 13.74 & 10.36 & 1.53 \\
Glass & 0.2 & 0.05 & 1 & 1.67 & 0 & 0.00 \\
Wood & 0 & 0.00 & 0 & 0.00 & 4.64 & 0.69 \\
Others & 0 & 0.00 & 2.65 & 4.41 & 3 & 0.44 \\
Total & 418.62 & 100.00 & 60.06 & 100.00 & 676.68 & 100.00 \\
\% Total & 28.26 & - & 4.05 & - & 45.68 & - \\
\hline
\end{tabular}

In $57 \%$ of shops, organic waste is thrown away because it is not required when a product has been made/prepared, i.e., in the case of a butcher, skins, bones, fat or offal, and that of a fishmonger, skins, guts and heads. More than half (54\%) of stallholders surveyed said that this is the main reason why they throw away their waste. Twenty six percent throw away organic waste because it is made up of damaged products that cannot be consumed. Twenty percent dispose of waste because it is composed of surplus products that have failed to sell. 
Table 9. Distribution of the total waste generation by type of shop (b).

\begin{tabular}{ccccccc}
\hline & $\begin{array}{c}\text { Greengrocers } \\
\text { (kg/day) }\end{array}$ & $\mathbf{\%}$ & $\begin{array}{c}\text { Bakeries } \\
\text { (kg/day) }\end{array}$ & $\mathbf{\%}$ & $\begin{array}{c}\text { Frozen Food } \\
\text { Shop (kg/day) }\end{array}$ & $\%$ \\
\hline Meat or fish & 0 & 0.00 & 0.2 & 0.80 & 0 & 0.00 \\
Fruit and vegetables & 124.37 & 44.19 & 0 & 0.00 & 0 & 0.00 \\
Paper and cardboard & 84.56 & 30.05 & 12.64 & 50.32 & 1 & 50.00 \\
Plastic & 12.15 & 4.32 & 3.53 & 14.05 & 1 & 50.00 \\
Glass & 0 & 0.00 & 0 & 0.00 & 0 & 0.00 \\
Wood & 60.34 & 21.44 & 0 & 0.00 & 0 & 0.00 \\
Others & 0 & 0.00 & 8.75 & 34.83 & 0 & 0.00 \\
Total & 281.42 & 100.00 & 25.12 & 100.00 & 2 & 100.00 \\
\% Total & 19.00 & - & 1.70 & - & 0.14 & - \\
\hline
\end{tabular}

Thirty six percent produce mixed waste and put all of it in the same container, due to the fact that $95 \%$ of shops do not have separate containers that allow for the separation of waste (the remaining $5 \%$ recognize that although there are containers in the marketplace to separate waste, it is easier or faster to dispose of it all in the same place). With respect to how organic waste is deposited in the container, in $88 \%$ of cases, it is inside disposal bags, and only $11 \%$ is done in bulk.

As for the possibility of donating food, in $17 \%$ of shops, food waste is thrown away; in $40 \%$, food surpluses are donated somehow; and in 70\% of cases, they are handled differently, such as to feed animals or to produce other products, such as breadcrumbs. If a classification is carried out by type of activity, $44 \%$ of the food surplus from greengrocers is donated, followed by fishmongers (33\%) and butchers and delicatessens $(27 \%)$. The shops where most surpluses are thrown away are the fishmongers (18\%). Many traders claim not to have a daily surplus, because what they are not able to sell they can preserve due to the food characteristics (this is the case in delicatessens) or they can preserve food under refrigeration for several additional days (as in butchers or fishmongers).

In none of the cases in which donations are made is this done in a coordinated way by the marketplace. Most of the donations are made once a week (41\%). Thirty seven percent of donations are made more than once a week and $22 \%$ sporadically. The annual average of donations by shops stands at $329.33 \mathrm{~kg}$, the maximum being $1080 \mathrm{~kg}$.

Considering only the shops that do not make donations, $49 \%$ are interested in starting to donate food, 37\% would deliver fish and 32\% meat. To a lesser extent, there are delicatessens $(21 \%)$, greengrocers $(11 \%)$ and bakeries $(11 \%)$ that would donate; $68 \%$ of shops that are interested in donating could do it sporadically.

Finally, $61 \%$ said that a food pickup system, shop by shop, would be the best practice, and $27 \%$ consider that food donated should be kept cold. The possibility of providing a shared container or space in the marketplace in which to deposit donations only convinced $15 \%$ of traders.

\subsubsection{Cluster Analysis of Results}

When the descriptive analysis was completed, we tried to better classify the shops of Asturian marketplaces in order to adjust the proposals for improvements that would increase donations. Therefore, we decided to carry out a cluster analysis where the only classification variable used is the total amount of organic waste generated by each shop, which is justified because the aim is to recover the food surpluses of this economic activity and, thus, to reduce the organic waste stream.

After checking the normality of the classification variable chosen (using a Lilliefors test) and the prerequisite of sample representativeness (that is met by the high response rate, over $70 \%$ of the target population according to Table 4), the suitable number of clusters to obtain was determined, and the result was two (according to the method of hierarchical clusters). When analyzing the dendrogram (or the distance matrix), the existence of two different clusters with different sizes of grouping of shops in Asturian marketplaces was detected. Then, a new cluster analysis using the algorithm k-means confirmed the previous result. To ensure the validity of the previous classification, a discriminant 
analysis (employing the Wilks lambda method) was conducted, including the classification variable. This test allowed the rejection of the null hypothesis of equality in the averages of the discriminant function between the two groups identified as commercial shops.

In Table 10, shops belonging to each group are described. In Cluster A, there are 13 commercial shops that generate in their daily activities eight-times more organic waste than businesses in Cluster B. In addition, in Cluster A, all organic waste comes from meat and fish, while Cluster B also generates waste from fruit and vegetables, although on average, slightly lower amounts. Shops in Cluster A also belong to marketplaces privately managed under administrative concessions.

Table 10. Main characteristics of the clusters.

\begin{tabular}{|c|c|c|c|}
\hline & Variable & Cluster A & Cluster B \\
\hline & Tumber of shops & 13 & 96 \\
\hline & Type of activity & $30.8 \%$ butchers, $69.2 \%$ fishmongers & $\begin{array}{c}35.4 \% \text { butchers, } 17.7 \% \text { greengrocers, } \\
13.5 \% \text { fishmongers }\end{array}$ \\
\hline Ava & ilable surface $\left(\mathrm{m}^{2}\right)$ & 25.5 & 17.9 \\
\hline Availa & oility of cold chamber & $100 \%$ Yes & $92.7 \%$ Yes \\
\hline & Daily clients & 110 & 67 \\
\hline Mark & etplace management & $46.2 \%$ private concession & $45.8 \%$ public management \\
\hline & Waste mixture & $30.8 \%$ & $36.5 \%$ \\
\hline & arated containers & $77.8 \%$ blue, $44.4 \%$ yellow & $65.6 \%$ blue, $34.4 \%$ yellow \\
\hline Org & nic waste (kg/day) & 40.385 & 5.288 \\
\hline \multirow{3}{*}{ Wastes } & $\begin{array}{l}\text { Meat and fish } \\
\text { (kg/day) }\end{array}$ & 40.385 & 3.976 \\
\hline & $\begin{array}{l}\text { Fruit and vegetables } \\
\qquad(\mathrm{kg} / \text { day })\end{array}$ & 0.000 & 1.313 \\
\hline & Others (kg/day) & $\begin{array}{l}2.9 \text { paper and cardboard, } 0.9 \\
\text { light packaging }\end{array}$ & $\begin{array}{l}2.7 \text { paper and cardboard, } 1.9 \text { wood, } \\
0.7 \text { light packaging }\end{array}$ \\
\hline \multicolumn{2}{|r|}{ Types of waste } & $\begin{array}{l}100 \% \text { preparation, } 38.5 \% \text { leftovers, } \\
38.5 \% \text { no available for consumption }\end{array}$ & $59.8 \%$ preparation \\
\hline \multicolumn{2}{|c|}{ Donation frequency } & $33.3 \%$ once a week, $33.3 \%$ sporadically & $77.8 \%$ once or several times per week \\
\hline \multicolumn{2}{|c|}{ Annual donations (kg/year) } & 100 & 317 \\
\hline
\end{tabular}

Shops in marketplace Type A could potentially offer more donations (each one generates much more organic waste than shops of Type B, about eight-times more by weight as seen in Table 10), and they are located in marketplaces where donations would be easily coordinated, because they are better managed (public ownership and private management, which is embodied in a clear and customized command unit integrated for specific management positions).

In Cluster B, there is the largest number of shops, a total of 96, with more diverse activities. Most of the marketplaces where these facilities are located are managed directly by the local public administration, which is also who owns them. Each shop of Type B generates an eighth of the waste, compared to the other cluster, which was partially balanced by the amount (the number of shops is more than seven times that of Cluster A) and its greater propensity to donate (more than double in frequency, more than triple in quantity). However, they are located in the worst managed marketplaces (dispersion among various public offices, lack of specific management positions, slow political decisions, etc.).

In light of these data, it seems advisable that information campaigns about organic waste management and promotion of altruistic donations of food surplus are refereed differently for each cluster, taking into account both the type of majority activity and the management model in its marketplace. 
Food banks are non-profit organizations, and they have scarce resources (especially economic ones). Attending to the cluster analysis results, the food bank in the region studied must focus on the sensibilization campaigns to shops and marketplaces belonging to Cluster A for the following reasons:

- As Cluster A only has 13 shops, the food bank does not need too many resources to inform/make contact with them.

- These few shops are the greatest generators of food waste. If they are properly managed, the flow of food donations could be increased considerably.

- These shops are dedicated mainly to selling meat and fish, which are basic items for a nutritional and balanced diet.

- These shops belong to privately-managed marketplaces, so the presence of an administrator could help to begin organizing the food donations.

\subsubsection{Estimations of Potential Food Recovery}

Once the potential of food donations from marketplaces is clear, the next research step is estimating the quantities that could be recovered.

Firstly, depending on the type of property/management, it has been found that marketplaces differ from one another. Therefore, they can be classified into three types (Table 11): Group I (integration of two marketplaces municipally owned, but privately run through an administrative concession), Group II (in which there are six marketplaces with municipal property and management) and Group III (that consists of a single marketplace privately owned and operated). This first step has shown a better understanding by the two managers belonging to marketplaces in Group I; in Groups II and III, the absence of a central manager made it difficult to obtain information in some cases, and it was necessary to contact several people from different departments or areas involved.

Table 11. Classification of marketplaces.

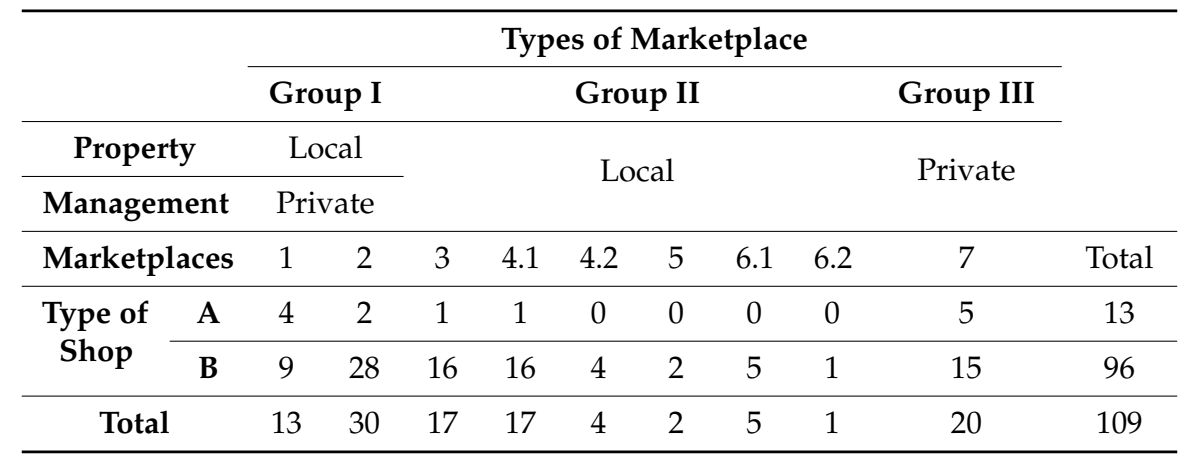

The total daily generation of organic waste in all of the Asturian marketplaces was estimated at $1797 \mathrm{~kg}$ (Table 12), which means about 561 tons per year. In addition, these marketplaces could recover annually for social purposes at least 36 tons of food (Table 13), a figure that cannot be considered really high compared to that of the more than 858 tons per year recovered by the food bank in the region during 2014 [18]. The study should now be revised and extended to other types of commercial shops or food waste producing entities. However, donations of fresh food that are highly demanded by the final recipients can be observed.

Furthermore the greatest quantities of fresh food waste in marketplaces are produced by fishmongers; this result is not exactly equal to the food losses in the distribution and sales in the USA, Canada, Australia and New Zealand, for which seafood was in second place after fruit and vegetables [5]. 
Table 12. Estimation of daily organic waste generated.

\begin{tabular}{ccccc}
\hline $\begin{array}{c}\text { Type of } \\
\text { Activity }\end{array}$ & $\begin{array}{c}\text { Average } \\
\text { Organic Waste } \\
\text { (kg/day) }\end{array}$ & $\begin{array}{c}\text { Total Estimation of } \\
\text { Organic Waste (kg/day) } \\
\text { in the Sample }\end{array}$ & $\begin{array}{c}\text { Total Estimation of } \\
\text { Organic Waste (kg/day) } \\
\text { in Non-Participants } \\
\text { (Outside the Sample) }\end{array}$ & $\begin{array}{c}\text { Total Estimation } \\
\text { of Organic } \\
\text { Waste (kg/day) }\end{array}$ \\
\hline Butcher & 8.66 & 459.06 & 17.32 & 476.38 \\
Delicatessen & 2.55 & 38.15 & 5.10 & 43.25 \\
Fishmonger & 30.71 & 921.31 & 122.84 & 1044.15 \\
Greengrocer & 6.91 & 172.74 & 34.55 & 207.29 \\
Bakery & 1.25 & 11.45 & 2.50 & 13.95 \\
Other (food) & 0.77 & 3.90 & 7.70 & 11.60 \\
Total & - & 1606.61 & 190.01 & 1796.62 \\
\hline
\end{tabular}

Table 13. Estimation of potential annual donation.

\begin{tabular}{cccccc}
\hline & \multicolumn{2}{c}{ Marketplaces in the Sample } & \multicolumn{2}{c}{ Marketplaces outside the Sample } \\
\hline $\begin{array}{c}\text { Type of } \\
\text { Activity }\end{array}$ & $\begin{array}{c}\text { Average Donation } \\
\text { (kg/year) }\end{array}$ & $\begin{array}{c}\text { Total } \\
\text { Shops }\end{array}$ & $\begin{array}{c}\text { Donations } \\
\text { Estimated (kg/year) }\end{array}$ & $\begin{array}{c}\text { Total } \\
\text { Shops }\end{array}$ & $\begin{array}{c}\text { Donations Estimated } \\
\text { (kg/year) }\end{array}$ \\
\hline Butcher & 219 & 53 & 11,607 & 2 & 438 \\
Fishmonger & 394 & 30 & 11,820 & 4 & 1576 \\
Greengrocer & 358 & 25 & 8940 & 5 & 1788 \\
& & & 32,637 & & 3802 \\
\hline
\end{tabular}

\subsection{Suggestions for Guidelines to Improve Recovery and Donation of Food}

In more detail, the cluster analysis provided a division of the shops into two groups. Cluster A, nearly eight-times smaller than $B$, is integrated mainly by private management marketplaces. They are shops formed by butchers and fishmongers with an average generation of organic waste much higher and with fewer tendencies to donate than Cluster B. Cluster B is also formed by greengrocers and other food shops that generate less waste and donate more. These results promote a more initial intensive awareness campaign from food banks to shops belonging to Cluster A due to the fact that they produce greater quantities of food waste, but they are a smaller number of shops (so it is easier and less expensive to carry out donations successfully).

Looking at the results obtained, three groups of recommendations and improvements are suggested considering both the type of management and the cluster to which it belongs (Table 14).

Table 14. Classification of marketplaces for recommendations.

\begin{tabular}{lccc}
\hline & Group I & Group II & Group III \\
\hline Cluster A & & - & \\
\cline { 1 - 1 } Cluster B & Marketplaces 1 and 2 & Marketplace 7 \\
\cline { 3 - 3 } & & Marketplaces 4.2, 5, 6.1 and 6.2 & \\
\hline
\end{tabular}

The role of the different stakeholders in the organic waste supply chain is crucial for successful results. Therefore, recommendations for future improvement actions are focused directly on the different players involved in each marketplace: town hall, manager and sellers.

In Group I, the proposals are different for Clusters A and B, but similar in Marketplaces 1 and 2, due to the fact that they have the same management model, and in both, the figure of the manager is clear. For instance, Cluster A shops belong to butchers and fishmongers that generate large quantities of organic waste, where more than half are not recoverable, being bones, skins and fish heads, all of them coming from product preparation; they have to be informed of the correct disposal methods for 
these kinds of waste. The Cluster B shops have to be made aware of the new rule for putting organic waste into a separate dustbin.

In Group II there are also different proposals, but both for Cluster B, because only two shops of this group belong to Cluster A (Table 11), and it is not worth making differentiated efforts for them. On the one hand, an action plan has been devised for Marketplaces 3 and 4.1, because they have the same management model and the same number of shops (16). On the other hand, proposals and improvements are made for Marketplaces 4.2, 5, 6.1 and 6.2, which have a local management and a low number of shops open.

Group III is only integrated for Marketplace 7, which has a great number of active shops. Two different action plans for sellers, one for shops in Cluster A and another one for Cluster B, are elaborated with reference to the special features of this marketplace.

Tables 11 and 14 are the combination of the classification obtained from the qualitative study (Groups I, II and III according to management) and the quantitative study using cluster analysis (Clusters A and B). As expressed in the previous paragraphs, this classification determines how improvement proposals would be applied in practice, because the number and type of shops and the management model in each marketplace must be taken into account. These proposals, which are then expressed as a list of general recommendations, are aimed at the key stakeholders: managers, administrators and traders. Then, as a first general measure, a basic recommendation is made to the marketplaces belonging to Group II (public administration): the management should be centralized in a person belonging to a specific department within the council (environment, works contracts, heritage, etc.).

Following the results and once all marketplaces have a person in charge, either a manager, administrator, president or similar, the following guidelines for these people are proposed:

- Establishing a fluid relationship between the waste manager and the Food Bank of Asturias, through frequent meetings on the requirements for collection, monitoring, etc.

- Training for traders on bio-waste and awareness, through information and motivation sessions, as well as posters or other local/inexpensive broadcasting media.

- Providing appropriate resources for separate collection and donations. Managers of marketplaces should supply traders with waste containers and adequate space for them.

- Control of the new collection: the manager must be aware of the degree of daily filling of organic waste containers and what shops are donating or are interested in donating.

- Dissemination and marketing of good performance towards customers, through display panels and leaflets in the collaborator shops and other similar means.

All of these improvement proposals, firstly for managers and later for traders, could have a general interest in order to be extrapolated to any marketplace.

As for the specific proposals to traders, several measures can be identified:

- Control of the amounts of waste generated: Traders should be knowledgeable about the quantities of waste from their shops and the economic value of these.

- Minimization of bio-waste: Managing organic waste is meaningless if the reduction of its production has not been previously tried by protecting products adequately.

- Awareness campaigns on the situation of certain disadvantaged collectives in order to prioritize the surplus as donations for human consumption.

- Collaboration agreement between beneficiary entities and donor shops to quickly co-manage edible food for human consumption.

- Traceability guarantee of food donated by invoices delivered by traders to the recipient entities. 


\section{Conclusions}

Currently, urban waste has increased significantly in cities, becoming a concern for society and even more so for policy makers and waste managers who need to find solutions to give waste a proper output and adapt themselves to the new rules that affect their activity. In particular, food marketplaces are typically organic waste generation spaces and present an interesting potential to promote the minimization, donation and recycling of that waste.

The main objective of this research was to study the management of bio-waste in Asturian marketplaces to facilitate separate deliveries of suitable food surpluses for donations or to value the usable remains. Finally, nine Asturian marketplaces, belonging to seven different councils that seem sufficiently representative, were studied.

The results of this research show the potential of food marketplaces as donors to food banks and other beneficiary entities. Although the estimates of the potentially recoverable amounts may seem small compared to the amounts currently managed by any food bank represented by the Food Bank of Asturias, they have a great importance because of their character, i.e., fresh food, which is in high demand by the final beneficiaries, who suffer significant shortcomings of this kind of product.

Another research concern is the need to meet legal requirements and to ensure the required sanitary conditions, the main concern being the maintenance of the cold chain. Health inspectors consulted assured us that food from marketplaces could be donated if the European regulation is taken into account, the agreements between food business donors and recipient organizations about which products are acceptable are made clear in writing, and the organizations are responsible when transporting them and are able to store them appropriately.

Because donations from marketplaces are very perishable products and have consequent difficulties, as other authors, such as Gunders [5] and O'Donnell [45], state, it is necessary to have available a very finely-tuned system to avoid incurring risks to human health. Therefore, for the successful organization of donations, a proximity methodology must be applied [46], because there is no material time to ship products through a central platform (the Food Bank of Asturias in this case), so they should be delivered directly to beneficiary entities with their headquarters next to each marketplace. There are two types of beneficiary organizations [47]: distribution and consumption; the first ones distribute food received among the beneficiaries of the entity; the consumption entities prepare and serve food in their soup kitchens after collecting donations. It seems logical that consumption organizations are the most appropriate for these donations from marketplaces because they can provide faster output of perishable foods, by cooking and serving them on the day of receipt. However, in any case, both donors and recipients must be provided with the necessary technical resources for preservation to ensure that food will be consumed appropriately from the point of view of health conditions.

The second step of the study, surveying traders of the same nine marketplaces for information on quantities of waste, surplus and donations, was justified by the fact that they are the ones who can provide more specific data, disaggregated day-to-day on marketplace activity. We must not forget that they also have an important role in the adoption of measures to help improve the management of such waste. Surplus donations were an issue that had been in the air in the qualitative analysis; therefore, much of the survey and data processing are focused on this aspect. The descriptive analysis allowed us to obtain relevant data on waste quantities and management, which were later used in a cluster analysis to classify shops.

One of the main conclusions of the research carried out is the role of a manager in charge of decision making in each marketplace as a key factor, and the relationship with the type of property/management of the marketplace. For this and other reasons explained at the end of Section 3.2.2, the scarce efforts and resources of food banks or other charitable non-profit organizations must be focused on stalls and marketplaces belonging to Cluster A (all of them are privately managed and have a clear person in charge). In marketplaces where a manager does not exist, this responsibility should be assigned. 
Previous improvements (see Section 3.3) could also be considered in other research focused on other, different parts of the food waste management supply chain.

This research has enabled the staff in charge of the food bank in the region analyzed to see the potential of the food marketplaces as food donors. These commercial places had not previously been addressed for that non-profit entity. Furthermore, the results of cluster analysis have allowed them to better focus their initial efforts to undertake the successful performance and awareness campaigns. Thus, in the near future, food will be conveniently channeled in order to be consumed by human beings, avoiding harmful landfill (both for environmental and social reasons). Therefore, the research question has been answered, and the potential of organic waste in marketplaces as consumable food has been clearly demonstrated.

Although the fieldwork has been carried out in a small region in the north of Spain, the methodology applied could be replicated in order to estimate the potential food recovery nationwide or in other countries. In fact, the literature review found several fresh food recovery experiences from marketplaces in Cataluña, suggesting the interest of expanding the study initially to the national level. Anyway, most of the qualitative results and reflections above are easily extrapolatable and adaptable to any First World region.

Apart from the size of the covered geographic area, other limitations of this research and suggestions for future developments come up, firstly, from the fact that the study has not been carried out in depth in all Asturian marketplaces, in many cases through the lack of a clearly-defined head manager. Moreover, none of the people interviewed knew the exact data on the amount of waste produced in their marketplace, limiting their responses to approximations of the percentages of the fractions generated. Furthermore, the potential estimation of donations indicates a really low figure. Another interesting way to investigate this topic should deal with incentives for both reducing waste and donating recoverable products beyond a moral obligation, as well as the costs of the required infrastructure. All of these limitations could be lessened by additional surveys, direct observation or sampling of waste in each marketplace. Finally, it has also been found that many marketplaces have reduced their activity and changed their buying habits as a result of the actual economic crisis; one clear effect of this is the priority given to other shops, such as supermarkets or shopping centers, to which the research should be extended.

Acknowledgments: This research has been funded by the Ministry of Economy and Competitiveness (DPI2013-41469-P). In addition, part of the empirical work has received funding from the City Council of Gijón through the University Institute of Industrial Technology of Asturias (IUTA), SV-15-GIJON-1-11 project. Finally, we must acknowledge the cooperation of both the Food Bank of Asturias and COGERSA (Initials in Spanish for Consortium for Waste Management of Asturias), as well as the marketplaces and health inspectors and other staff, without whose participation conducting this research would not have been possible.

Conflicts of Interest: The authors declare no conflict of interest.

\section{References and Notes}

1. World Bank. Available online: www.bancomundial.org/odm/pobreza-hambre.html (accessed on 25 February 2016).

2. United Nations. The Millennium Development Goals: Report 2014; United Nations: New York, NY, USA, 2014.

3. Parfitt, J.; Barthel, M.; Macnaughton, S. Food waste within food supply chains: Quantification and potential for change to 2050. Philos. Trans. R. Soc. 2012, 365, 3065-3081. [CrossRef] [PubMed]

4. Food and Agriculture Organization. The State of Food Insecurity in the World 2012; Food and Agriculture Organization of the United Nations: Rome, Italy, 2012.

5. Gunders, D. Wasted: How America is Losing up to 40 Percent of Its Food from Farm to Fork to Landfill; NRDC (Natural Resources Defense Council): New York, NY, USA, 2012.

6. Hall, K.D.; Guo, J.; Dore, C.C. The progressive increase of food waste in America and its environmental impact. PLoS ONE 2009, 4, e7940. [CrossRef] [PubMed]

7. Boletín Oficial de las Cortes Generales. Comisión de Agricultura, Alimentación y Medio Ambiente, Proposición no de Ley 161/003764. Congreso de los Diputados 2015, 684, 15-16. 
8. MAGRAMA-Ministerio de Agricultura, Alimentación y Medio Ambiente. Estrategia: Más Alimento, Menos Desperdicio. Programa Para la Reducción de las Pérdidas y el Desperdicio Alimentario y la Valorización de los Alimentos Desechados; Ministerio de Agricultura, Alimentación y Medio Ambiente: Madrid, Spain, 2013.

9. HISPACOOP (Confederación Española de Cooperativas de Consumidores y Usuarios). Estudio Sobre el Desperdicio de Alimentos en los Hogares; HISPACOOP: Madrid, Spain, 2012.

10. Alexandre, C.; Smaje, C. Surplus retail food redistribution: An analysis of a third sector model. Resour. Conserv. Recycl. 2008, 52, 1290-1298. [CrossRef]

11. Starkey, L.J.; Kuhnlein, H.V.; Gray-Donald, K. Food bank users: Sociodemographic and nutritional characteristics. Can. Med. Assoc. J. 1998, 158, 1143-1149.

12. Starkey, L.J.; Gray-Donald, K.; Kuhnlein, H.V. Nutrient intake of food bank users is related to frequency of food bank use, household size, smoking, education and country of birth. J. Nutr. 1999, 129, 883-889.

13. Cotugna, N.; Vickery, C.E.; Glick, M. An outcome evaluation of a food bank program. J. Am. Diet. Assoc. 1994, 94, 888-890. [CrossRef]

14. Martins, I.; Guedes, T.; Rama, P.; Ramnos, J.; Tchemisova, T. Modeling the problem of food distribution by the Portuguese food banks. Int. J. Math. Model. Numer. Optim. 2011, 2, 313-341.

15. Handforth, B.; Henkick, M.; Schwartz, M.B. A qualitative study of nutrition-based initiatives at selected food banks in the Feeding America Network. J. Acad. Nutr. Diet. 2013, 113, 411-415. [CrossRef] [PubMed]

16. González-Torre, P.L.; Coque, J. How is a food bank managed? Different profiles in Spain. Agric. Hum. Values 2016, 33, 89-100. [CrossRef]

17. FESBAL (Spanish Federation of Food Banks). Available online: www.fesbal.org (accessed on 25 February 2016).

18. Banco de Alimentos de Asturias. Available online: www.bancaliasturias.org (accessed on 25 February 2016).

19. Hanlon, P.; Madel, R.; Olson-Sawyer, K.; Rabin, K.; Rose, J. Food, Water and Energy: Know the Nexus; GRACE Communications Foundation: New York, NY, USA, 2013.

20. BOE. Ley 22/2011, de Residuos y Suelos Contaminados, 181, 85650 a 85670 . Available online: http:/ / www. boe.es/boe/dias/2011/07/29/pdfs/BOE-A-2011--13046.pdf (accessed on 25 February 2016).

21. MINETUR-Ministerio de Industria, Turismo y Comercio. Estudio y Guía Para la Gestión de los Residuos en Mercados Municipales; Final Report of Results; MINETUR e Institut Cerdá: Madrid, Spain, 2005.

22. Maestre Montserrat, M.; Puig Ventosa, I. La canalización de excedentes alimentarios como estrategia local de prevención de residuos. IndustriAmbiente Gestión Medioambiental y Energética 2014, 4, $22-27$.

23. Sherman, E.A.; Reid, W.J. Qualitative Research in Social Work; Columbia University Press: New York, NY, USA, 1994.

24. Yin, R.K. Case Study Research: Design and Methods; Sage Publications: Thousand Oaks, CA, USA, 2009.

25. Gibbert, M.; Ruigrok, W.; Wicki, B. What passes as a rigorous case study? Strateg. Manag. J. 2008, 29, 1465-1474. [CrossRef]

26. Strauss, A.; Corbin, J. Basics of Qualitative Research: Techniques and Procedures for Developing Grounded Theory; Sage: Thousand Oaks, CA, USA, 1998.

27. Díez, E.J. Investigación-Acción participativa: El cambio cultural con la implicación de los participantes. Revista Electrónica Interuniversitaria de Formación del Profesorado 2013, 16, 115-131.

28. Mercados Municipales En Asturias. Available online: http://www.mercadosmunicipales.es/Mercados / inventario_y_recorrido.html (accessed on 2 October 2014).

29. Cámara de Comercio de Madrid. Madrid Comercio. Los Mercados de Madrid; Cámara de Comercio: Madrid, Spain; Available online: www.madridcomercio.org (accessed on 1 December 2015).

30. Alonso Gordón, R. Los mercados detallistas municipales en España: Presente y futuro. Situación, problemática, perspectivas y soluciones. Distribución y Consumo 1999, 44, 7-16.

31. Medina Pindado, Y.; Naud Velázquez, D.; Nieto Cuesta, B.; Oltra González, I. Mercados Municipales; Universidad de Valladolid: Castilla-León, Spain, 2012.

32. Alonso Gordón, R.; Estrada-Nora Rodríguez, M.; Sartorius, A. Los Mercados Minoristas Como Motor Para el Desarrollo Económico, Social y Cultural de una Ciudad; Fondo Multilateral de Inversiones, Banco Interamericano de Desarrollo: Washington, DC, USA, 2007.

33. Martín Cerdeño, V.J. Mercados municipales: La respuesta de los consumidores. Distribución y Consumo 2010, $109,15-28$. 
34. Torres Outón, S. Problemática actual de los mercados de abastos a través de un caso de estudio. In Proceedings of the VII Portuguese Conference on Sociology, Oporto, Portugal, 1-3 July 2012.

35. La Nueva España-Las Plazas de Abastos Están en Peligro por el Auge de los Súper, Según el Principado. Available online: http://www.lne.es/economia/2010/01/28/plazas-abastos-peligro-augesuper-principado/865510.html (accessed on 25 February 2016).

36. Generalitat de Catalunya. Guía de Prácticas Correctas de Higiene Para el Aprovechamiento Seguro de la Comida en los Sectores de la Restauración y el Comercio Minorista; Agència de Salut Pública de Catalunya: Barcelona, Spain, 2013.

37. Regulation (EC) No 178/2002 of the European Parliament and of the Council of 28 January 2002, laying down the general principles and requirements of food law, establishing the European Food Safety Authority and laying down procedures in matters of food safety.

38. La Vanguardia. Reus Rescata con Éxito Alimentos Frescos a Punto de Caducar. Available online: http: / /www.lavanguardia.com/20101105/54065399965/giralt-esteve.html (accessed on 24 October 2012).

39. Grupo Impulsia. Adiós al Carnet de Manipulación de Alimentos. Available online: http:// www.grupoimpulsia.com/index_htm_files/MANIPULADOR\%20DE\%20ALIMENTOS.pdf (accessed on 27 May 2015).

40. Fundación Alicia Y UAB. ¡A Aprovechemos la Comida! Una Guía para Reducir el Despilfarro Alimentario en el Sector de la Hostelería, la Restauración y el Catering; Universidad Autónoma de Barcelona: Barcelona, Spain, 2013.

41. Molina Azorín, J.F.; López Gamero, M.D.; Pereira Moliner, J.; Pertusa Ortega, E.M.; Tarí Guilló, J.J. Métodos híbridos de investigación y dirección de empresas: Ventajas e implicaciones. Cuadernos de Economía y Dirección de la Empresa 2012, 15, 55-62. [CrossRef]

42. Young, K.D.; Lewis, R.J. What is confidence? Part 2: Detailed definition and determination of confidence intervals. Ann. Emerg. Med. 1997, 30, 311-318. [CrossRef]

43. Saunders, M.; Lewis, P.; Thornhill, A. Research Methods for Business Students; Prentice Hall: Harlow, UK, 2012.

44. Trespalacios, J.A.; Vázquez Casielles, R.; Bello Acebrón, L. La Investigación de Mercados; Thomson Paraninfo: Madrid, Spain, 2005.

45. O'Donnell, T. Household Food Waste Pilot Project. The Last Food Mile Conference. 2014. Available online: http://repository.upenn.edu/thelastfoodmile/sessions/session/23 (accessed on 22 April 2016).

46. Falasconi, L.; Vitturari, M.; Politano, A.; Segré, A. Food waste in school catering: An Italian case study. Sustainability 2015, 7, 14745-14760. [CrossRef]

47. Berner, M.; O'Brien, K. The shifting pattern of food security support; food stamp and food bank usage in North California. Nonprofit Volunt. Sect. Q. 2004, 33, 655-672. [CrossRef] 